\title{
Gender and Rural History: A Roundtable
}

ana Cabana, Henry French, Colin R. Johnson, Leen Van Molle, Micheline Cariño (Editor), José Vicente Serrão (Editor)

KEYWORDS: gender, rural history, historiography.

JEL CODES: N01, N50, Z10.

7 he aim of this debate article is to promote a discussion of a historiographical nature (not ideological, not political) about the meaning, place and role of gender in both the rural past and the rural historiography. The discussion revolves around a variety of questions, ranging from the relevance, the opportunity and the very history of the use of gender category in rural history, to the analysis of gender (im) balances in the community of historians working in this broadly defined field of studies, not to mention the very definition of what is meant by gender. These and other related topics, for which there are no single or definitive answers, are debated here in a roundtable format. 
Recepción: 2021-09-10 • Revisión: 2021-10-29 • Aceptación: 2021-11-02

\section{CONTRIBUTORS}

José Vicente Serrão (editor) (orcid.org/0000-0003-0450-8648) is professor of Early Modern History at the University Institute of Lisbon (ISCTE-IUL). His fields of research, teaching and publication have been mainly the rural, economic, social and population history of early modern Portugal and Europe, with a more recent focus on property rights in colonial settings and on rebellion and resistance in the Iberian empires. He is co-founder and currently president of 'Rural RePort' (Portuguese-speaking Network of Rural History), member of CORN (Comparative Rural History Network), chief editor of journal Ler Historia, and was, inter alia, the chairman of past international conference on "The Global Challenges of Rural History" (Lisbon 2016).

Micheline Cariño (editor) (orcid.org/0000-0003-2627-9508) is teacher and researcher at the UABCS. She is a Doctor in History from the EHESS, Paris, France. She has coordinated and participated in more than 40 research projects on three main lines of research: world and regional history of pearls; relations society / nature, conservation and sustainability in the Gulf of California region; knowledge and sustainability of the South Californian oases. She is author and editor of 21 books, 73 articles and 80 book chapters. She has supervised 10 bachelor's theses, 16 master's theses and 15 doctoral theses.

Ana Cabana (orcid.org/0000-0002-5316-2631) is currently Associate Professor in the Department of History at the University of Santiago de Compostela and researcher in the Group 'Histagra', specialized in contemporary agrarian and rural history. Her research interests center upon the everyday life under Franco's regime and the study of social attitudes towards the dictatorship. Her research also includes commons and social movements and gender in rural areas. She has written papers and several books on these topics, including the most recent 'Haberlas, haylas', Campesinas en la historia de España del siglo XX (Madrid, Marcial Pons, 2021, with Teresa María Ortega).

Colin R. Johnson (orcid.org/0000-0002-4836-1417) is Associate Professor of Gender Studies and Adjunct Associate Professor of History at Indiana University Bloomington (USA), where he also holds affiliate appointments with the Department of American Studies, the Human Biology Program, and the Kinsey Institute. Johnson is the author of fust Queer Folks: Gender and Sexuality in Rural America (Temple University Press, 2013), which was finalist for the Lambda Literary Award, and co-editor of Queering the Countryside: New Frontiers in Rural Queer Studies (New York University Press, 2016).

Henry French (orcid.org/0000-0002-5101-4782) is professor of Social History at University of Exeter. He was chair of the British Agricultural History Society (BAHS) between 2016 and 2021. He has published several studies of rural society in England, including The Middle Sort of People in Provincial England (Oxford, 2007), and (with Richard Hoyle), The Character of English Rural Society: Earls Colne 1550-1750 (Manchester, 2007), and articles on the use of urban common lands. In addition, he conducted a research project with Mark Rothery (University of Northampton) on ideas and practices of masculinity among the English landed elite, published as Man's Estate: Landed Gentry Masculinities 1660-1900 (Oxford University Press, 2012).

Leen Van Molle (orcid.org/0000-0001-7415-5388) is full professor emerita of Social History at the KU Leuven (Belgium). Her research focuses on social policies, social movements and the construction of social identities, from 1800 to the present. She published widely on the history of the rural world, gender, poverty and charity, and the methodology of oral history. She is co-founder and former president of AVG-CARHIF (Archive and Research Centre for Women's History, Brussels) and EURHO (European Rural History Organisation), and currently president of ICAG (Interfaculty Centre for Agrarian History, KU Leuven). 


\section{INTRODUCTION}

José Vicente Serrão and Micheline Cariño. Nearly 50 years since the first overt claims to inscribe gender (then called "women") in history, no one nowadays disputes the relevance of a gender approach and the added value it represents in all domains of historical scholarship, including rural history - a label used here to name the scholarly field that deals with all aspects related to land, agriculture and rural society in the past. So, in a sense, gender is no longer an issue. Nevertheless, discussing the relationship between gender and any field of studies, as is the case with rural history, raises a number of pertinent and stimulating questions. Some are theoretical, conceptual and methodological in nature. Others refer to the relative weight that should be given to gender within the discipline when compared to other approaches and lines of inquiry. Others concern the very "reality" that is the object of study, namely which research topics are consistent or not with a gender approach and which ones should be prioritized. Still others are, let's say, more professional in nature, such as whether there is, and why, a possible imbalance in the number of female and male scholars working in the area, or whether there is inequality of opportunities and responsibilities in publishing, attaining positions, etc. And the list of possible questions could easily go on.

Although such issues are often addressed, they are usually so on an individual basis only by the specialists in the area in their own books and articles. What has been surprisingly lacking is an explicit debate within the discipline among people who have different views, degrees of commitment and priorities with regard to these matters. That is why we decided to organize and publish this collective debate article, which is intended to promote a discussion of a strictly historiographical nature (not ideological, nor political) about the meaning, the place and the role of gender in both the rural past and the rural historiography. It is important to emphasize that it was conceived as a free, open and inclusive debate, with no preconditions nor predefined conclusions.

The format of this article is that of a roundtable (a set of questions, each one followed by a round of answers) to which we invited four historians who, in addition to having already published and reflected on these issues, represent a balance of gender, generational perspectives, affiliations and cultural backgrounds (see the brief bio-notes). This conversation (always by email exchanges) took place in the spring of 2021 and it followed a twostep procedure. Firstly, the contributors were asked to respond separately to a set of five common questions; later, these first drafts were circulated and each author was invited to comment on the responses of the other tablemates. It is worth noting that the panelists were asked to limit their responses to a total of 2,500 words, which certainly did not allow them to fully develop their arguments, and also that, concerning "style", all contri- 
butions were expected to be written in a rather informal way (as if in a live roundtable), though supported when needed by the appropriate references.

As to the questions we have prepared to guide the debate, they were designed to be open enough to cover as many topics as possible and to give room to different, even opposite, views on the matter. So, in order to make clear from the beginning what we are talking about, we start by asking the panelists what is meant by gender in rural history research, since the very meaning of the word is far from obvious. Besides the difference between gender and women - which raises a conceptual discussion not yet fully resolved - gender has been used in research with at least three different meanings. Sometimes gender is simply taken as a category of analysis, in the same way we use other social, economic or physical variables (e.g. age, race, type of markets, soils quality, climate, etc.) to analyze and interpret data. In other cases, gender refers to the research topics, when these are perceived as more closely connoted with the label, corresponding not exactly to a gender history but to what we might call the history of gender in the rural world, although for the most part it is basically a history of women. Finally, we have gender as a perspective, that is, as a comprehensive and coherent way of looking at agriculture and rural society through the (theoretical, methodological) lenses of gender - it is what we might call the fully asserted gender approach to rural history. The fact is that these various meanings, which are not mutually exclusive, do represent different ways of dealing with gender in rural history research, as well as different degrees of commitment to the gender issue. All valid, of course, including the option, which we left out of this debate, of not using gender.

After discussing the meaning, we feel it is useful to search for a bit of history. In the answers to the second question, the reader will find a lot of information, as well as a critical appraisal, about how, when, by whom and with what results the gender approach entered and has evolved in rural historiography. There are two aspects that stand out in this survey. One is that the vast majority of the authors cited are women, something that, after all, is common to all fields of gender studies. The other is that the arrival of gender concerns in the field of rural history - even more so if we consider the "old", narrower, labels of agrarian or agricultural history - has been comparatively late and slow. Actually, both aspects are connected to each other and most likely the explanation for the second lies in the marked gender gap (more men than women) that has persisted in the discipline until very recently. What are the reasons for such a gender gap, why have women taken so long to become interested in rural history, and, in a more general way, how different can a rural historiography done by men or by women be - these are the questions addressed in the third round. 
Since there is still considerable room to deepen the incorporation of gender into the study of agriculture and rural society, the last questions we brought to the table are intended to discuss how, by whom and to what extent it should be done from now on. Firstly, in a more speculative vein, we invite the panelists to elaborate on the following question, which is perhaps the most challenging one: should we have a gendered rural history or should we simply call for a better dialogue between gender history and rural history? This is not an artificial dichotomy because either solution points indeed to a different direction and with different results. The first option, much more radical, ultimately demands rural history to take the "gender turn", which could call into question the very identity of the discipline and would not take into account that most researchers in the field do not prioritize a gender approach. The second option responds to the reality of the Academy, where there is a kind of division of labor and demarcation of territory between the disciplinary fields, even if disciplinary boundaries are increasingly fluid and researchers adopt multiple identities nowadays. Since both rural history and gender history are already consolidated scholarly fields, perhaps a better interdisciplinary dialogue could favor a smooth and fruitful exchange of concepts, vocabulary, methodologies and research questions, without any of the disciplines losing their basic and distinctive identities. But this is definitely an open question.

In the meantime, regardless of the big options, there are a number of small concrete steps that can be taken towards, say, a more gender-sensitive rural historiography, as the panelists were asked to suggest in the fifth section. Finally, in the last round (discussion) the contributors - who had written the previous responses separately - were given the opportunity to comment on the other tablemates' views and to make a final statement.

It is not our role to summarize the findings of this debate (that is up to the reader) but, just as a short final note, it can be said that the contributions collected from the authors - whom we thank for having so enthusiastically and so productively engaged in this project - show that despite some subtle (or not so subtle) differences, there is a great convergence of views regarding the main points. It would be somewhat different, of course, if we had taken a slightly daring option, adding to the panel someone else not so explicitly committed to a gender approach, which could help us understand the other angle of the question, that is, why so many scholars in the field (male and female), probably the most part, though not opposing, do not feel the need to incorporate gender into their studies.

However, as proponents and editors of this roundtable, we do believe that its main goals have been accomplished: the reader will now be more informed about what has been done in the field, will feel stimulated to keep thinking about the relevance of a gender per- 
spective to the knowledge of the rural past and will find some inspiring ideas on how to deal with it.

\section{WHAT IS GENDER IN RURAL HISTORY RESEARCH? DO YOU UNDERSTAND IT PRIMARILY AS A SUBJECT, AS A CATEGORY OF ANALYSIS OR AS A PERSPECTIVE?}

Ana Cabana. In my view, these are not mutually exclusive options; they all have their meaning and relevance, although they entail different results. Scholarly literature confirms that gender has gained weight for rural history and as a category, as an analytical tool that needs to be incorporated into historical accuracy, in order to examine in detail specific components of rural social aggregates in different contexts. However, I think it would be very desirable that gender becomes a perspective. This would be positive in order to achieve a transversality which would ensure a real and continued impact of gender in rural history. As a theme or as a category as Joan Scott (1986) defined it, gender is constrained; it works as a fenced field in which it is marked who enters and for what purpose. It acts as an enclosed area on which committed researchers or occasional onlookers can work. As a defined field of study, it runs the risk that its achievements will not be recognised by the meta-narratives of rural history, given the often subaltern profile of the individuals studied. If we were able to turn it into an approach, a gaze, all these restrictions would privilege an integral enrichment: any researcher, regardless of their area of interest and methodological tools, could be impelled to integrate the gender perspective.

Colin R. Johnson. I tend to think Joan Scott got it right in her 1986 essay, "Gender: A Useful Category of Historical Analysis", where she defined gender as "a constitutive element of social relationships based on perceived differences between the sexes" and, crucially, "a primary way of signifying relationships of power." She also went on to observeor, really, at that point, postulate-that "[c]hanges in the organization of social relationships always correspond to changes in representations of power, but the direction of change is not necessarily one way" (Scott 1986, 1067). In other words, for Scott, and for me as well, gender has an indexical quality relative to power that makes visible, or at least discernable, shifts in the structural organization of the social as such, whatever that is. As a discursive formation that has the conceit of difference at its core, and that is powered by ongoing contest over the nature and meaning of difference, gender also tends to influence, and be influenced by, other difference-based discourses including race, class, and sexuality. Indeed, as intersectional feminist scholarship has taught us, such discourses are often virtually impossible to pull apart from one another, even for purely heuristic purposes. 
This much seems true generally. That is, it seems as true of gender's meaning and utility in the context of research dealing with rural history as it is in the context of research that deals with anything else. What may differ about gender's meaning and utility where rural historical research is concerned, however, is the degree to which the power dynamics that structure social relationships in rural contexts are settled and stable rather than dynamic, or at least the degree to which they are imagined to be settled and stable, which obviously isn't quite the same thing.

The only caveat I would add to Scott's formulation, based on several decades' worth of subsequent research by feminist and queer scholars, is that power often serves to maintain as much as it does to transform. In that sense, representations of power, and of gendered social relationships, are exceedingly difficult to read-more difficult, in any event, then I think they were often assumed to be early on, when feminist scholars tended to conceptualize gender as an analytic tool that could help them understand, and ultimately contest, the persistence of patriarchy. For example, it took a while for scholars to distinguish gender normativity from gender hierarchy, and to describe the former as a related, but ultimately distinct, function of the operation of power. From my perspective, at least, gender hierarchy has received a fair amount of attention in the scholarship dealing with rural history; gender normativity considerably less so.

Henry French. I think there are two dimensions to the study of gender in rural history research. The first is well-known and well-established, the second less so. The first is the task of inserting the analytical category and methodological insights of gender history into the study of agrarian or rural history. This grew out of the earlier desire of women's history to emphasize the necessity of understanding the contribution of women in history more generally. In line with the evolution of the subject, it has moved towards thinking about gender as a category for historical inquiry, in ways outlined by Joan Wallach Scott's seminal essay (Scott, 1986). However, a great deal of work on gender in rural history concentrates on the history of women, because there remains so much still to recover of women's experiences and contributions, and to understand about the structural disadvantages, discrimination and restrictions that constrained the lives, and determined the strategies, of women in rural society in the past.

We can see some of the main categories of recent research in the submissions of panels to next year's EURHO conference in Uppsala. While gender might be the subject of many individual papers, there are eight panels (out of a total of 82) where it is explicit in the title. Four relate to the burgeoning area of women's work in rural society particularly in the early modern era, and focus on new techniques for uncovering its extent and measuring its contribution to household economies. There are equivalent ses- 
sions on women, farm work and gender relations in the nineteenth and twentieth centuries, respectively. There are also panels on widows and family survival strategies, and women's contribution to agrarian change in the twentieth century, through education and technical knowledge, and through their contribution to recent agrarian crisis responses. A panel on agricultural education for children since the eighteenth century must surely be likely to mention the influence of gender, too. In the recent past, there have also been extensive debates about the lack of parity between male and female earnings in agriculture, and whether this reflects structural discrimination or different working patterns derived from gendered norms about women's family responsibilities (Burnette, 2009).

The other dimension is really the reverse of the first: how can agrarian history contribute to our understanding of concepts of gender? This is much less well explored historical territory. When historians of gender think of locations in which gendered identities are constructed or contested, they do not tend to think of rural society. Katherine Jellison's keynote paper at EURHO 2019 in Paris was one attempt to do that for German migrant communities to the USA in the $18^{\text {th }}-20^{\text {th }}$ centuries. Instead, historians have tended to think of urban life, and its capacity to foster sub-cultures in which traditional gender identities are questioned or subverted. However, there is surely scope to think about the ways that depictions of rural femininity or masculinity, of peasant life and labour, influenced models of gendered identity, particularly in the industrial era (Sayer, 1995). This has been explored in the context of Socialist and Fascist depictions of heroic labour (e.g. McCallum, 2018), but more could be said about how gendered experiences and images of rural life contributed to the creation of the most-honoured and other, more subversive ideas about femininity or masculinity (e.g. Sangeres, 2002).

Leen Van Molle. I consider gender in the first place as a category of analysis, an analytical focus on the constructed character of masculinity and femininity in time and space. Gender history is thus, fundamentally, a history of human relations, a way to make sense of the $\mathrm{m} / \mathrm{f}$ way of life in the past. One of the more recent insights is that 'gender' is just one of a wider set of socio-cultural markers, next to class, ethnicity, sexuality, nationhood, age, philosophy of life, ... Each individual and group identity is the result of the interaction of such "complicating categories" (Boris \& Janssens, 2000).

Ensuing from this, the self-perception and way of life of gendered identities might not only differ between the countryside and the urban realm, but also within the rural community, between for instance landlords, larger farmers, peasants and agricultural wage labourers, between inhabitants and seasonal labourers, between the farming class and rural shopkeepers, etc. Consequently, the gender perspective adds to a far deeper under- 
standing of the features and functioning of rural societies, internally and in their interaction with others.

\section{HOW WOULD YOU ASSESS, IN RETROSPECT, THE PRESENCE (OR INFLUENCE, OR CONTRIBUTION) OF A GENDER APPROACH TO RURAL HISTORY SCHOLARSHIP DURING THE PAST 20-30 YEARS?}

Ana Cabana. This focus on gender has renewed research in rural history in recent decades. One of the most outstanding contributions has been to question and, as a byproduct, to deny that in historical meta-narratives the generic masculine was an inclusive neuter. Scholars have pointed out that this indefiniteness responded only to a hegemonic masculine. By clarifying that this was an epistemological and methodological bias, they have opened up to the diversification of historical subjects and subaltern genders and this has re-dimensioned their subjectivities and their central role in historical processes.

This achievement has demolished a fallacious conception incapable of overcoming the judgement of historical research, the one that converted inequality between men and women into something natural, beyond the scientific method itself. This body of research has turned gender inequality into what it really is: a practice rooted in the power relations within the rural world. Gender studies have revealed spheres, practices and discourses which construct and preserve the men/women inequality in rural areas and, in doing so, have historicised this marginalisation, just as they had already done with other causes of discrimination (economic, ethnicity, class, etc.).

Addressing gender has, more than anything else, given visibility to women. This research has vindicated their role in peasant economies. The historical analysis of past rural societies in terms of gender has brought out an unknown and underestimated dimension of the subjectivity of rural women and their multiple trajectories, which has redefined them as a decisive category. Since Joan Jensen in 2000 drew attention in her essay "Now you see her, now you don't" to the gap between the significance of women in the peasantry and their lack of reflection in history books, much progress has been made. In this way, a review of the literature of recent decades shows the rise and consolidation of lines of study that recognise women's agency. They have been made visible in areas that had been largely a male domain. One could cite a subject that has seen a recent boost, such as criminality (see Rachel Jones, 2016; Harvey Osborne, 2016). But if one had to point out a specific field, it would be "women's work": the analysis of women as a workforce, measurable through the incorporation of unpaid and therefore socially reviled labour into the category of "work", whether in the domestic and/or reproductive sphere, in the 
agricultural sphere or in the domestic sphere (Sarah Whatmore, 1991; Patricia O'Hara, 1998).Women are, nowadays, less "Invisible Farmers" than they were when Carolyn Sachs (1983) called them so. Also noteworthy is the attention given to wage discrimination (Carmen Sarasúa, 2021) or to the dichotomous distribution of farm work as a reflection of the gendered cultural stereotypes (Karen Sayer, 1995; Susan R. Grayzel, 1999).

This progress tends, however, to equate "gender" and "women" and, in so doing, blurres the boundaries of two distinct categories. This has led to a direct identification of the male-female binary system and a preference for the analysis of sexual dimorphism rather than the female-male cultural construct. It is worthy pointing out the research beyond this practice, which includes not only female subjects but also femininities and masculinities under the spotlight, as John Mack Farragher (1981) demanded decades ago and as authors such as Margreet van der Burg (2002) and Joan Jensen (2006) have been doing. In addition, I want to highlight those groundbreaking works that make visible other collectives and identities that were shaped in relation to gender without falling into the traditional binomial (Colin R. Johnson, 2013).

Colin R. Johnson. First, I think it is important to acknowledge that there is some truly excellent scholarship floating around out there that deals with gender and the history of rural life. In the US context, which is the context I am most familiar with, I immediately think of the work of people like Paula Baker (1991), Valerie Grim (2012), Lu Ann Jones (2002), Mary C. Neth (1998), and Nancy Grey Osterud (2012), to name just a few examples of scholars who have helped to blaze the trail in this domain. It is worth noting that the bulk of this work proceeds under the auspices of what scholars in the field of Gender Studies sometimes refer to as the "women and..." paradigm, which is to say a paradigm in which women's marginalization, both as historical subjects and as subjects of historical inquiry, is mitigated, however imperfectly, by recentering their experiences, perspectives, interests, and voices. And there is nothing inherently wrong with this approach. In fact, scholarly work of this variety, which is often also avowedly feminist work, has been essential to breaking the proverbial logiam of gender-indifferent scholarship on rural and agricultural history — scholarship that, traditionally, could only be bothered to speak of women when they could be characterized as somebody's mother or somebody's wife (typically "the farmer's," always presumptively male).

Studying gender involves more than the study of women, however. In fact, it involves more than the study of women and men. It also involves the study of masculinity and femininity, and the highly mobile, occasionally non-existent, boundary between them. It involves the study of both the alignment and non-alignment of sex and gender. It involves the study of other forms of relationality that sex and gender help to structure, like sexu- 
ality. And, as Joan Scott suggested, it involves thinking of gender in terms of power, a point Katherine Jellison made very clear she understood when she titled her 2009 study of US farm women and technology during the first part of the twentieth century, Entitled to Power. Mostly, though, taking a serious approach to the study of gender in any scholarly domain means refusing to treat sex and gender as self-evident; it means refusing to take the question of what sex and gender are, or what they do, or how they work, for granted, either individually, or in tandem. This, I think, is an area where the existing scholarship could stand to be improved, or at least to continue to grow.

Henry French. As I have suggested, I think the contribution has been primarily to insert gender into agrarian history, and particularly to give much greater attention to the contribution of women to rural society, rural households, labour patterns and earnings. The focus on women's work in the early modern period by my colleague Jane Whittle, Maria Ågren in Sweden and debates involving Joyce Burnette, among others, have created new methodologies to explore women's work in rural Europe (Whittle, 2019; Ågren, 2017; Burnette, 2008). The parallel development of interest in the 'household economy' has also enabled a re-thinking of the kinds of contributions made by women, men and children to this collective (if highly unequal) enterprise (Hartman, 2004; Humphries \& Weisdorf, 2015). Alongside this, there have been many studies considering women and property rights to land, women and the management of land, and women's contributions to farming, food preparation, animal husbandry, rural marketing, rural industries, and credit networks to name but a few (Erikson, 1993; Capern et al., 2019; Roberts, 1979; Sharpe, 1996; Verdon, 2002; Spicksley, 2007; Goose, 2007). There have been fewer selfconsciously gender historical analyses of men in rural society. One interesting example was in EURHO 2019, in the panel on single men in the countryside, and their social isolation or integration ${ }^{1}$.

Leen Van Molle. The gender approach has indeed influenced agricultural and rural history, and luckily, for if it had not, the field would have lost a sizeable part of its credibility. Let us not forget that many disciplines went, from the 1960s onwards, through a threefold process of epistemological self-criticism that hit historiography as well. Women's history, the first innovation, presented itself as a critique of the well-established his-story. It produced, on the one hand, a "celebratory" and "compensatory history" (Lerner, 1975) in order to add the names of forgotten female heroes and victims to the standard tale of the past. And it unveiled, on the other hand, the separate female world of home making, child rearing, sewing, cooking etc. But both approaches proved unsatisfactory: because

1. See http://ruralhistory2019.ehess.fr/wp-content/uploads/sites/35/2019/04/PROGRAMME_ EURHO_2019.pdf. 
of their rather descriptive nature, because they isolated the history of women and its female writers in a separate field, and because they reinforced rather than solved the debate about equality versus difference between the sexes.

Gender goes beyond this dichotomy; the concept generated a second revision of many disciplines. The concept was introduced to the historical metier by Joan Wallach Scott in her groundbreaking article of 1986, and it has opened up a fantastic new playground for historians. The past, indeed, unveils how gender shaped asymmetrical power relations, and how power reinforced the asymmetry between contructions of masculinity and feminity. Thanks to the awareness of gender, historians were able to contribute to the undermining of our so-called western rational and Enlightened thinking. That is not nothing.

But gender is not a magic spell. With its firm focus on shared norms and practices, gender history risks, firstly, underestimating the agency of individuals and ignoring the diversity of human thinking, feeling and acting. Gender, secondly, proves to be a functional concept for the (historical) analysis of the West, but less for that of non-western cultures which emphasised other markers, age for instance (Boydston, 2008). And, thirdly, gender analysis risks reproducing the stereotypical binary, heterosexual way of thinking, without questioning the grey zones between or next to the dichotomy $\mathrm{m} / \mathrm{f}$ and including LGBT + . This last critique is currently producing a third revision in social sciences: namely the (re-)introduction of the body, not as an ahistorical given sex, but as part of varied and evolving sexual cultures and body politics. Or, in other words, a research that includes the questioning of the variable interdependence between nature and culture.

Was there an influence of all this on rural history? Yes: the three aforementioned historiographical shifts have been picked up, although, let us be honest, rather late and not massively. It is worth mentioning that there were a few remarkable forerunners: Nelly Schilstra with her PhD about female labour in Dutch agriculture and industry in the late nineteenth century (1940), the book by Inez Jenkins about the history of women's institutes in England and Wales (1953), and the one by Greta Smit about agricultural housekeeping in the Netherlands in the twentieth century (1966). But when analysing historiographical production since the 1970s (within my horizon, being the modern period and in Dutch, English, French and German), I cannot but observe its limitations. First, rural history has often been understood as agricultural history sensu stricto, dissociated from its broader social and gendered context. Agricultural knowledge, food production, agricultural markets and policies, second, have often been presented as driven by a genderneutral invisible hand, if not as an explicitly male undertaking. And, third, when women's history took off, it took a while before its potential trickled down to agricultural and rural history and engendered separate histories of farm and farming women. 
Joan Jensen is considered as the pioneering author in the field, with her book from 1981 on farming women of various racial backgrounds in the US, a book with the feminist message to "provide alternatives to the sexist texts used in school" (Jensen, 1981: ix). Nevertheless, it took another decade before the female perspective became a fashionable new way of looking at the countryside. Some authors chose a regional approach (for instance: Neth, 1995; Albers, 2001; Verdon, 2002), many focused on organizations of farming women (such as: Cohen, 1990; Andrews, 1996; Ambrose, 2000; Sawahn, 2009), others opted for revealing thematic approaches such as the contribution of women to botany and agronomy, female landownership and the Women's Land Army (Shteir, 1996; Inhetveen \& Schmitt, 2000; White, 2014; McDonagh, 2017). However, in 2005, French historians were still wondering whether a French history of farming women would be possible ... (Sainclivier, 2005).

A decade earlier, gender had started to slip into the vocabulary of rural historians, almost silently and initially as an uncomprehended concept, without any theoretical reflection, as emerges from the introductions to the pioneering special issues on "Women and Rural History" (Rural History 1994) and on "Rural and Farm Women in Historical Perspective" (Agricultural History 1999). But as time evolved, more and more (female) rural historians made good use of the analytical potential of gender to unravel the constructionist dimension of rural femininity (for example Ulbrich, 1995; Sayer, 1995; Jones, 2009). So too did a few (male) authors, though somewhat later, as they began to study rural masculinity and sexuality in the countryside, two still under-researched fields (Johnson, 2013; Froissart \& Terret, 2014; Anderson, 2020). Abundance is not particularly a feature of the rural history of gender and sexuality. There are reasons to advance the idea that the gender turn has left, more and more profoundly, a far earlier mark on rural sociology, anthropology and geography ${ }^{2}$.

\section{FOR SOME REASON, THERE HAS BEEN AND STILL IS A MARKED GENDER GAP (MORE MEN THAN WOMEN) IN THE COMMUNITY OF PEOPLE WORKING ON AGRICULTURAL HISTORY. HOW WOULD YOU INTERPRET THIS? HOW DIFFERENT CAN A RURAL HISTORY MADE BY WOMEN OR BY MEN BE?}

Ana Cabana. Agrarian history is not the only case of a gender gap in Academia, nor is it even different from other fields within history: history of violence and/or war or na-

2. Cf. the revelatory but rather ahistorical book by the ethnologist SEGALEN (1980); many articles in Sociologia Ruralis, especially BRANDT (2002); with regard to geography: LITTLE \& PANELLI (2003). 
tionalism studies, for example. The causes behind the gender gap are similar in all instances. The professional choices are biased by cultural factors that guide women in certain directions and expel them from other paths; academic environments explain this directionality and even women's own self-discrimination. Two factors affect this "not so free, not so individual" decision not to work in rural history. The first one would be the lack of female role models (female professors, principal investigators, etc.), which acts as a brake on young female students. To subvert this, it would make sense to adopt inclusive/parity policies in the management and composition of professional institutions (Societies, Associations, etc.) as well as at conferences or chairmanships. And the same would apply to journals of agricultural history, with the aim of providing a greater diversity of authorship, on editorial or review committees, etc. Ensuring this need not be at conflict with quality. On the contrary, it should be one step closer to the objective of equity, which should be a mark of normality in research.

The second factor would be cultural stereotypes, much more profound and difficult to tackle than the mere scarcity of female scholars of reference. In particular, the idea of a supposed empathy or sensitivity inherent to women, which still casts women into social history, cultural history or women's history. All of these are areas in which the characteristics socially attributed to females seem to entail greater capacities and better abilities. Both of these factors, a shortage of role models and stereotyped images, feedback into each other and often influence students' choices.

Regarding the second question: rural history made by men and women is better than rural history made by one or the other exclusively, just like any discipline. And it is even better if it is done by women and men of different ages, ethnicities, social classes, religions, socio-economic and geographical backgrounds and sexual orientations. Diversity is the greatest guarantor of equity in scholarly work: the research questions, the goals, the perspectives and the sensitivities in perception would be unique and, therefore, enrich theory and praxis.

Colin R. Johnson. I guess I would like to start by pointing out that agricultural history and rural history are not the same thing, at least in my opinion. To be sure, agriculture figures prominently as a concern in much of the literature I know that deals with the history of rural life. And certainly, much of the scholarship that deals with the history of agriculture, properly speaking, attends to the non-metropolitan contexts in which farming and other practices associated with farming have tended to take place. That does not mean that agriculture is synonymous with rurality, however, or that the study of the history of rural life necessarily entails focusing primarily on agriculture as a practice or system. The distinction is important because I am not sure I entirely agree with the premise of the ques- 
tion, and I think part of the reason I do not agree with it is that I see a much greater imbalance between the number of men and women working in agricultural history than I do in rural history, where my sense is that women are really leading the field in some respects. As for why that is the case, I am not entirely sure. Perhaps the history of agriculture feels to many women in the profession like a sub-specialization within the history of science and technology, and perhaps many of those same women simply have more pressing concerns, like why we can split the atom but cannot seem to end sexism. What I do know is that any field of scholarly inquiry is diminished when it lacks diversity. So if there is a significant gender imbalance in either field, that's something scholars associated with the field should be very concerned about, especially if they have a genuine investment in ensuring that it remains a vibrant and viable one moving forward.

Henry French. I think that rural history suffers the same structural issues as the wider discipline of history, and the same problems that men predominate in positions of authority, whether on editorial boards, funding councils, senior university positions, doctoral supervisors and so on. That said, there appear to be a couple of issues specific to rural history. In many European countries, my impression is that rural history remains a sub-set of economic history, where a tendency remains for cliometric approaches to be regarded as more rigorous, and social/cultural/gender approaches as less rigorous. There is no intrinsic reason why women should favour one approach or be discriminated against more by one approach rather than the other, but this may contribute negatively to the gender gap. There might also be the association of gender history with women's history, which may mean that some historians who study subjects in which gender has an active role, do not think of themselves as studying the subject, because their research focus is not specifically on women.

In Britain, the problem is different because economic history is much less widely researched than in many European countries, and rural history lost its methodological and institutional links to it 20-30 years ago (as economic history departments closed). The problem in the UK is that few scholars identify themselves as rural or agrarian historians, even if they study rural or agrarian themes. Instead, they regard themselves as historians of landscape, rural protest, poverty, animal histories, women and technology, government agrarian policy, or rural politics, but would be unlikely to attend conferences in the field of agrarian or rural history per se.

Leen Van Molle. The problem is double. First: agricultural history itself lost a part of its appeal in the last decades of the twentieth century, at least in Europe. Agriculture vanished from the horizon for most people and interest in agricultural history declined correspondingly. Second: the traditional, gender-neutral cow and plough history was partic- 
ularly unattractive to female historians, who were themselves rare birds in academia. Hence, perhaps the need for the small club of rural women's historians to join forces and increase their visibility: in 1998, they established the Rural Women's Studies Association, built as it were on previous conferences from 1984. The association aims at promoting "farm and rural women's gender studies in a historical perspective". But, noteworthy, its triennial conferences have remained, up to now, as good as exclusively North American gatherings ${ }^{3}$.

In terms of research, the turn towards social and cultural history, discourse analysis and gender, heralded a game changer. Gender functioned in this respect as the leverage with which to overcome the ghettoization of women's history. The widening of the historiographical scope to a vast range of agriculture-related topics has attracted a new generation of rural historians, male and female, who easily meet and interact because they share common new scopes and methods to unmask the past. They study - more or less including perspectives on gender and sexuality - definitions of rurality, environmental risks, colonial encounters, power relations, the construction of sciences and technologies, knowledge transmission, famines, food cultures, etc. Tellingly, the Rural History conference in Leuven in 2017 welcomed 405 delegates, of which no less than $45 \%$ were female. Male and female scholars, a different rural history? I am not sure, or rather: I am sure that each historical publication bears the stamp of its author's skill, creativity and world view. A more varied academic community is the best insurance to get a multifaceted and better-balanced interpretation of the past, and that is an asset.

\section{SHOULD WE HAVE A GENDERED RURAL HISTORY OR SHOULD WE SIMPLY CALL FOR A BETTER DIALOGUE BETWEEN GENDER HISTORY AND RURAL HISTORY, CONSIDERING THAT BOTH OF THEM HAVE ALREADY CONSOLIDATED THEIR OWN IDENTITY AS SCHOLARLY FIELDS?}

Ana Cabana. They should coexist. I plead for an integrative effort between these two areas as a guideline. From this work, which should move from the multidisciplinary to the interdisciplinary, emerging projects should develop an inclusive rural history. Rural history must empower itself as a discipline and not give up on responding to the challenges posed by a gendered rural history. The future lies in introducing gender into our $\mathrm{PhD}$ and master's training programmes. This would make it possible, in addition to the obvious ben-

3. The website of the Rural Women's Studies Association is based at Ohio University. 
efits of a grounded knowledge of gender studies and its methodologies, to enhance the gender perspective as relevant and interesting in the construction of an improved historiographical account of the rural past. This would give research in peasant history much greater autonomy than working with gender specialists which, however attractive and practical it may be - which it is, I repeat - means that historiography and its own interests cease to set the pace; it means waiting for gender scholars to turn our object of study into their object of interest, which means a certain subordination. Championing a gender history without delay is more possible if those of us who already work on rural history adopt the gender perspective.

Colin R. Johnson. Honestly, I don't think we can really avoid having a gendered rural history. At least among human beings, gender is a factor in the functioning of the world whether we choose to acknowledge that fact or not. And it has been for a very, very long time. What we can do, however, is willfully ignore the extent to which the rural history we have is always already gendered, bearing in mind that one of the forms male privilege sometimes takes (along with white privilege, and heterosexual privilege, and cisgender privilege, etc., etc., etc.) is false universalism. And to some extent I would argue that we have willfully ignored the degree to which false universalism haunts all sorts of historical scholarship, particularly historical scholarship we otherwise love. Let's be honest: it takes work - conscious, intentional work - to write half the world's population out of the history of anything; and really more than half the world's population when we start dealing with other forms of historically significant alterity, like race and class. That includes the history of anything that happened in rural areas. Similarly, it is a choice simply to assume that everyone's desires run in the direction of the "opposite" sex (note the scare quotes). We need to stop making these kinds of choices. In their place, we need to start choosing to ask ourselves what difference gender makes in the stories we are trying to tell in our work. In much the same way, we really should be asking ourselves what difference race makes, or class, or sexuality. There may very well be instances in which the answer is "not much, or least not much that I feel equipped to account for or explain." And that is perfectly fine. Well maybe not perfectly fine. I can understand it, though. Indeed, I appreciate it when scholars are explicit about the limits of their own expertise. If nothing else, such admissions help to make clear that scholars who do specialize in the study of gender, or race, or sexuality have something genuinely important-indeed one might go so far as to say essential - to contribute. What I cannot abide is seeing the consideration of gender treated as a niche concern, or as no concern at all.

Henry French. It is really a question of the intellectual purpose that would be served by creating a gendered rural history. If by this we mean a strand of rural history that uses gender, gender concepts and gendered identities to interrogate existing assumptions, and 
existing subject definitions that might be a very good thing. An analogy might be decolonization initiatives in History, which have interrogated and exposed the inherent Western-bias in many fundamental concepts used within History, from ideas of development, to what constitutes capitalism or a peasantry (Davis, 2011). However, in general it appears that gender is being assimilated as an additional analytical or conceptual tool, within the existing tool-kit of agrarian historians. This is the general trend for new approaches to History, as they simply add to the range of methods by which we explore the subject. As I have suggested I think there is scope for rural history to feed back into the development of understandings of historical gender identities. We should not see the intellectual traffic as one-way, from gender history to rural history.

Leen Van Molle. Reductionism is always an impoverishment. Let us cherish the diverging paths of historical research because each scholarly field adds to the understanding of the past. Rural history and gender history both make sense. But this should not be at the expense of the pursuit of a holistic view: history itself was not fragmented, people in the past did not live in separated fields. The discovery of the networking of individuals and things, ideas, emotions and practices through time and space is one of the most challenging and rewarding tasks of a historian. Men and women in towns and the countryside shaped notions of rurality, and they shaped also each other's identity, according to circulating notions of gender, class, religion and other markers. The gender perspective should belong to the concerns of all historical research. It is satisfying to observe that recent historiographical criticism does take gender into account: Frank Uekötter's book on agricultural knowledge (2010), for instance, was criticized for its all too masculine view on agrarian knowledge production and diffusion ${ }^{4}$.

By the way: gender has changed rural history, but rural history has changed gender history as well. Whereas gender history often revolved around the male breadwinner ideology and the construction of separate spheres, agriculture history has shed light on wellaccepted opposite practices: in many regions and times, farming rested on male and female labour, on gendered cooperation and complementarity.

4. Review by Ernst Langthaler, Archiv für Sozialgeschichte online, $4^{\text {th }}$ April 2011. 


\section{WHAT COULD BE DONE IN ORDER TO ENCOURAGE A MORE GENDER-SENSITIVE RURAL HISTORIOGRAPHY? PLEASE SUGGEST YOUR PRIORITIES IN TERMS OF TOPICS, RESEARCH QUESTIONS, PROJECTS OR WHATSOEVER.}

Ana Cabana. It is a rather complex question; themes and research questions vary enormously depending on national/regional historiographies and on the historical period. I have made an attempt to reflect on the case of contemporary rural historiography in Spain, with which I am more familiar (Cabana, 2018; Ortega \& Cabana, 2021). Rural historiography in this country has made great efforts to make rural women visible and normalize their presence in research since the 1990s (Sarasúa \& Gálvez, 2003; Rey Castelao, 2015; Ortega, 2015; García González, 2020), although it cannot compare with the heyday that research on women has had in social, economic or cultural history. In any case, rural history would be more sensitive to gender if the potential of gender as an innovation within the grand narratives of rural history was truly perceived. At the last Symposium of the Sociedad de Estudios de Historia Agraria (Madrid, 2020), which included a seminar on gender, the panellists, Carmen Sarasúa, Teresa María Ortega and myself, agreed that if it were possible to demonstrate (more and better than has been done so far) the capacity for renewal that gender can have in rural history, then it would be possible to make a difference in rural history. This renewal would affect the very parameters that underpin our research, rooted in heteropatriarchy, and that would affect our major objects of study (institutions, property, policies and agrarian structures and revolutions, technological innovation, environmental and economic crises, social mobilisation, socio-cultural dynamics, etc.) and would even put on the table new alternative chronologies.

Moreover, like any field of history, rural history should be able to show itself (as well as anthropology, sociology, etc.) as an useful tool for the present-day socio-political agenda in which gender functions as a key vector - rural development, depopulation, environment, etc. - and this could be done from a gender-sensitive rural history. Rewriting the meta-narrative of rural history and ensuring equality in the shaping of new ruralities, as can be seen, is an enormous and tremendously suggestive challenge.

Colin R. Johnson. The first thing I would suggest we do is vanquish the notion that rural spaces are preserves of inherited custom and tradition. Or, at the very least, if we are going to account for distinctive aspects of rural life and rural history in terms of custom and tradition, we need to recognize that citing custom and tradition doesn't explain much of anything, in and of itself. It isn't just that historical continuity is often the result of active and intentional resistance to change, and that such resistances need to be brought to 
the surface and analyzed. It is that perceived stabilities and coherences quite often have profoundly consequential instabilities and incoherencies encrypted at their cores. This was one of the key insights of queer theory, and it is an insight that I personally think has potentially profound implications for the study of rural history.

Just consider the word "rural" itself. It is a fundamentally relational term whose meaning is ultimately contingent, to one degree or another, on our conceptualization of the urban. At the same time, it is different from that term "urban" in the sense that what it names seems woefully unspecific, especially the further back in history one goes. One might say, for example, that most of human history is both rural and agricultural in nature. Almost no one does, though. Instead, they periodize the pre-industrial era in a way that makes most of human history's conspicuous rurality, and its agriculture-centeredness, seem almost beside the point. At the very least, they routinely treat those aspects of the distant past as historical givens - things that serve to explain other things, rather than things that merit investigation and commentary on their own terms. We could stamp our feet and get all huffy about this. And believe me, I have. But we could also choose to take a step back from our frustration about the relative ease with which the category of the rural is subsumed into or overwritten by other frames of analysis and ask ourselves instead what analytic imperatives, or even just what analytic opportunities, rurality's internal contradictions and frayed conceptual edges create.

For example, it seems to me that the one important implication of the rural/urban binarism is that the salience of rurality as an analytic category actually increases as human societies become more urbanized. In other words, rurality's best days as a meaningful category of historical analysis, or at least its most consequential days, could very well lie ahead. That doesn't mean we should give up our interest in the distant past. But it could mean making more pronounced investments, as a field, in the study of recent history. Similarly, I would argue that we need to stop thinking about agriculture primarily as a vocation or mode of production and start thinking of it as a biopolitical regime that helps to naturalize what are ultimately cultural conceits about the distinction between things like production and sexual reproduction, the human and the non-human, and the natural and the social. These are distinctions my interest in gender and sexuality has obligated me to interrogate in my own work on the history of agriculture, especially, and I am certainly not alone in having done so (Johnson, 2013, especially 27-50; Rosenberg, 2015). I think there is much, much more to be said along these lines, however.

Finally, I really think we need to pay much closer attention to the body and embodiment. Other historical subdisciplines are rife with material that contends with the body and embodiment in fairly explicit terms, but I have always felt rural and agricultural his- 
tory shy away from these topics. Maybe that is simply because the source materials we use are more limited, or at least more modest in tone. I am not entirely convinced that is the case, however. In any event, it has always struck me as an odd zone of circumspection in the literature given how prominently the theme of physical labor's effect on the body figures in many accounts of rural life.

Henry French. For me, the main motivation to become interested in gender history was because I needed to think about it in order to improve my historical interpretations of class. I felt that I was missing out on a valuable concept, or rather, that I had been avoiding the subject area, because I did not understand it properly. One way to encourage the study of more gender-sensitive rural history is to demonstrate that the end result of such an approach creates explanations that are richer, more complete, more rigorous and more satisfying than those which exclude them.

While specialization and the development of a highly engaged strand of gendered rural history might break open some research topics and conceptual barriers, it might also create a defensive reaction. If one compares the effects of gendered approaches in the field of social or cultural history, since Joan Wallach Scott wrote her article in 1986, gender has just entered the mainstream of this subject. It is just one standard analytical category and conceptual category that historians include in their analyses, alongside class, faith, sexuality, race and so on, as well as studying the 'intersections' between these categories. I think this process is already under way in rural history, and I anticipate that the number of panels at EURHO (for example) in which gender is an explicit theme will grow from its current 10 percent to greater proportions, in the same way that EURHO has quickly integrated decolonizing histories and the Global South.

As I have suggested, one area for research might be for rural historians to think about how their subject area can contribute to debates in gender history. For example: (A) Did rural society possess, develop or retain its own specific notions of patriarchy, or household power structures, because of the distinctive patterns of female labour being identified there? (B) How did concepts of rural femininity or masculinity relate to changing notions of women's or men's identities in the industrial era, in particular? Was the rural regarded as a refuge from corrupting urban influences, or a brake on progress and a home to boorish identities? (C) How did concepts of gendered human identities influence the understanding of animals, animal behaviour, husbandry and science? (D) How did concepts of gender interact with ideas of regional identity, landscape and space? Did elites arrange rural women and men into typologies according to their abilities to cope with particular terrains or agrarian regimes (as they did in colonial contexts)? Were residents of uplands, mountain or pastoral areas said to possess different gendered characteristics to 
lowland, arable districts? Which was regarded as superior and why? How did these people think about such characteristics?

Leen Van Molle. More gender-sensitivity can begin, so I would suggest, with the introduction of a new routine to enhance the visibility of female researchers within the field: let us produce bibliographies with full first names, instead of initials that hide the gender of the authors (which can lead to embarrassing situations).

And further, with regard to rural history: instead of focussing on single issues, it can help to consider the whole agro-food chain, from the field to the fork. Both genders had a say - be it often an unequal one - in the consecutive aspects of the chain, from the various branches of food production (arable, livestock, vegetables and fruit), over food processing and preservation (dairy for instance), marketing (farm women as market-goers) and shopping, to cooking and consumption. With the agro-food chain in mind, one can bridge the typical cleavages in research between the male and the female perspective, the rural and the urban, the production and consumption side. In addition, we really need more comparative history. Seebohm Rowntree, a British observer, noted in 1910 that in certain parts of Belgium, womenfolk, together with some elderly and children, took on all the work on the farm while their husbands did wage labour. If contemporaries were surprised to discover important differences in female farm work between regions and countries, we have an open invitation to try to make sense of the variable ways that the farmer and farm woman have been constructed through time and space.

\section{FINAL DISCUSSION}

Ana Cabana. I believe that all our interventions share, broadly speaking, similar perceptions of the potential of gender as a vantage point from which to approach rural history studies. It is true that these perceptions are influenced, of course, by the contextual criteria in which we are anchored, whether by the periods and spaces in which our research takes place, or by our individual geographies.

As far as I am concerned, I would like to focus on an issue that seems to me to be of enormous transcendence and which has been dealt with more casually than, in my opinion, it should be. I am referring to the substantial contribution of intersectional analysis as a key to bringing a gender perspective to rural history studies. The concept of intersectionality was introduced by Kimberlé Crenshaw (1991) as a way of describing violence against black women through the interconnections between race and gender. The conceptualisation of intersectionality has been one of the most important contributions of 
feminist studies, as it allows for the theorisation of multiple intersecting oppressions, making possible a more complex and dynamic understanding of social relations and power structures that recognises differences between intersecting categories. The concept destabilises the conceptualisation of homogenous categories - such as "woman" or "man"and binary systems - such as feminine and masculine-, capturing the relationships between gender and other different dimensions of power structures (race, class, sexuality or age). Under an intersectional perspective, gender is not the only category or process that frames unequal vulnerabilities, but rather it is one more element for a historical research that must always be attentive to the heterogeneity of rural societies and cultures.

Thus, intersectionality provides rural history with another alternative in the treatment of gender, one that is different from the one most widely used by our scholars, as we have all verified in our responses, and which could be inscribed in what has come to be known as Herstory. It would be one defined by the attempt to make fair reparation for the invisibility of what has been done and achieved by women throughout history: certainly, we could all agree women's history is, even today, the untold story of rural areas' collective history. The risk of this option is that the contributions of research on rural women are relegated to an ad hoc space. This fact hardly modifies the canon.

Furthermore, as Adrienne Rich wrote, when explaining the impetus for her intellectual reflection, "re-visioning, the act of looking back — seeing with new eyes, entering into an old text from a new critical dimension-, is for us more than a chapter in cultural history: it is an act of survival" (Rich, 1972: 18). When approaching rural history, it could be said that gender constitutes that new look at the past the author mentions. A gendered rural history can reboot our analytical vision of the past rural world as successfully as, for example, the environmental perspective did decades ago. A new gaze which underpins, not its survival of course, but certainly its validity within the framework of the enormous variety of disciplines that have integrated gender into their theoretical postulates (ecofeminism, feminist economics, gender anthropology, etc.) and which, with this, have found a place in universities and research centres all over the world, reaching an editorial weight to be taken into account, a weight which demonstrates their transcendence.

Colin R. Johnson. One thing that really stood out for me as I was reviewing our collective response to the provocative questions presented to us was how seldom the matter of the environment came up. Leen and Ana included "environmental risks" and "environmental and economic crises" within longer lists of issues that rural and agricultural historians could address, and probably should address, especially if they want their work to remain relevant as we begin to contend seriously with the increasingly inevitable reality of climate change. But the environment as such wasn't really a significant point of concep- 
tual reference for any of us in our thinking about gender and rural history, or gender and the history of agriculture. There are probably reasons for this, including the sense I know many rural and agricultural historians share, that scholars of environmental studies are sometimes so scrupulously attentive to the inextricable interconnectedness of the human and non-human that the complex social, economic, and historical etiology of environmentally destructive human behavior almost begins to feel beside the point. Still, I am fairly sure that this discussion would differ in some important respects if the task at hand was thinking about the role gender analysis has played in environmental history, or environmental studies more broadly understood, rather than rural and agricultural history.

Among other significant differences between the field formations, and despite their many points of obvious connection, I would argue that scholars of environmental history tend to concern themselves more self-consciously with questions of justice and injustice than scholars of rural of agricultural history do. Or, at the very least, they tend to be more explicit about such concerns than scholars of rural and agricultural history often are. I don't think that's because historians of agricultural and rural life care less about justice than historians of the environment do. I think it's because, unlike rural and agricultural history, which began as, and to some extent remain, areas of subspecialization within the scholarly discipline, a point Henry makes, environmental studies and environmental history emerged in response to a social movement - the environmental movement. That matters in this context in much the same way it matters in a closely related context-namely, the evolving relationship between Women's Studies and Gender Studies. As Leora Auslander has noted, they differ somewhat in their methods and concerns partly because Women's Studies emerged in response to a specific social movement: the women's liberation movement. There was no comparable gender liberation movement which demanded structural change within the scholarly profession, however. Instead, the shift from Women's Studies to Gender Studies was arguably driven by fairly rarified debates among scholars themselves (Auslander, 2001). Here, the fact that the rural and agricultural history emerged as disciplinary subfields prior to the advent of the moden environmental movement obviously doesn't mean that rural and agricultural history can't engage with questions of justice and injustice-social, economic, environmental, or otherwise. Those fields may need to be more intentional about doing so, however, even at the risk of becoming somewhat presentist in their thinking regarding what specifically about the history of agriculture and rural life requires closer study or reconceptualization. In other words, we may need to focus less on what's interesting about rural and agricultural history and more on what's urgent about it.

Henry French. There is always a risk in these Socratic dialogues that someone will end up playing the role of Mediocrates, blithely summing up the views of the other participants 
and suggesting the pursuit of a middle way. I think I might be playing that part here. The discussion has highlighted some of the problems and opportunities of integrating gender into the study of agricultural and rural history. The problems outlined here by all the contributors include the danger that gender is simply added as another thematic category within existing fields of study, particularly when it is just bolted on to existing subjects (cheese making and gender etc). In particular, Colin Johnson and Leen van Molle have made a very powerful case not only for locating gender at the centre of analyses of agricultural practices and processes and rural life, but also to use it as part of a more fundamental rethinking of these subjects, as Johnson puts it, a rethinking that sees agriculture as a "biopolitical regime that helps to naturalize what are ultimately cultural conceits about the distinction between things like production and sexual reproduction, the human and the non-human, and the natural and the social". This encompasses van Molle's emphasis on thinking about the entire food chain, and Cabana's concern to use gender to help reconfigure the "very parameters that underpin our research, rooted in heteropatriarchy, and that would affect our major objects of study (institutions, property, policies and agrarian structures and revolutions, technological innovation, environmental and economic crises, social mobilisation, socio-cultural dynamics, etc.)".

I think we are seeing the kind of shift that Johnson advocates, albeit in slow-motion, and without the different themes being joined up. The concepts of agriculture and farming are being disrupted and re-conceptualised by radical shifts in thinking about ecology, biological exploitation and destruction or degradation, and in the animal turn which rethinks the human \& non-human divide and agency in agriculture. Similarly, a lot of attention has been paid to embedded patriarchal assumptions and institutions of property and law, government, knowledge and authority in agriculture, rural society and academic practice. Using these as a basis for rethinking histories of agriculture, rurality and rural society embeds gender within this re-thinking, and within an inter-sectional set of problematic concepts and categories with which to interrogate existing assumptions and interpretations. The worst thing a historian can try to do is predict the future, but I tend to think that this process will continue as it has done, by filtering through a range of different subject areas, pushed along by the odd paradigm-shifting monograph that spawns a host of subsidiary studies. The question is how far, and how fast, these aspects can be joined together into the more profound re-thinking of the subject that each of the contributors has argued is necessary. Hopefully this dialogue may have added a little impetus to this process.

Leen Van Molle. What struck me, first of all, is the notable degree of consensus among the four authors who were invited to contribute to this reflection on gender and rural history. Importantly, we all point to the relationship between gender and power relations, and 
at the inextricable intersection of gender with other markers, such as class, ethnicity, faith, etc. Or in other words, we all incite historians, more or less explicitly, to focus on the polymorphous constructions of inequality in the past, and that will help, undoubtedly, to unveil similar mechanisms at work in the present.

Anyhow, our shared understanding of the added value of integrating gender in history is promising for the future of agricultural and rural history. I am, by the way, convinced that one of the major challenges our world is facing right now, namely its ecological sustainability, will attract more and more attention to agriculture, rurality and nature, including their historical developments which were marked by gendered power structures. There is thus work ahead of us. But let us thereby avoid the pitfalls of essentialist and binary thinking, which we do in many ways: with regard to sexuality and gender, the ruralurban cleavage, nature and culture, traditions and modernity. Progress in the understanding of our gendered past and present is, I think, to be found in exposing the elasticity of individual agency, the categorical complexities (gender, age, race etc.), the many variations and "irregularities" (through time and space, within communities and families) and the fluidity of identity constructions. The past is not served by reductionist accounts of its history, nor is the present.

\section{REFERENCES}

ÅGREN, Maria (2017). Making a living, making a difference: gender and work in early modern European Society. Oxford: Oxford University Press.

Albers, Helene (2001). Zwischen Hof, Haushalt und Familie. Bäuerinnen in WestfalenLippe (1920-1960). Paderborn: Verlag Ferdinand Schöningh.

Ambrose, Linda (2000). Women's Institutes in Canada: The First One Hundred Years, 1897-1997. Ottawa: Federated Women's Institutes of Canada.

ANDERSON, Joseph L. (2020). You're a bigger man: technology and agrarian masculinity in postwar America. Agricultural History, 94 (1), 1-23.

ANDrews, Maggie (1996). The Acceptable Face of Feminism: The Women's Institute as a Social Movement. London: Lawrence \& Wishart.

Auslander, Leora (2001). Do Women's + Feminist + Men's + Lesbian and Gay + Queer Studies $=$ Gender Studies?. Differences, 9 (3), 1-30.

Baker, Paula (1991). The Moral Frameworks of Public Life: Gender, Politics, and the State in Rural New York, 1870-1930. New York: Oxford University Press.

Boris, Eileen \& JANSSENS, Angelique (eds) (2000). Complicating categories: Gender, Class, Race and Ethnicity. Cambridge: Cambridge University Press. 
Boydston, Jeanne (2008). Gender as a question of historical analysis. Gender $\mathcal{E}$ History, 20 (3), 558-583.

BRANDT, Berit (2002). Gender identity in European family farming: a literature review. Sociología Ruralis, 42 (3), 181-200.

BURG, MargreetVan der (2002). "No second farmer". Gender, agricultural modernisation and education for rural women in the Netherlands. Hilversum: Verloren.

BURNETTE, Joyce (2008). Gender, work and wages in Industrial Revolution Britain. Cambridge: Cambridge University Press.

BurnetTe, Joyce (2009). Reply to comments: Defining Gender, Work and Wages: A Roundtable Discussion. Social Science History, 33 (4), 495-504.

CABANA, Ana (2018). En femenino plural. La perspectiva de género en la historia rural. In David Soto \& José-Miguel LANA (Eds.), Del pasado al futuro como problema. La historia agraria contemporánea española en el siglo XXI (pp. 189-208). Zaragoza: PUZ.

Capern, Amanda L., McDonagh, Briony \& Aston, Jennifer (2019). Women and the Land 1500-1900. Woodbridge: The Boydell Press.

Cohen, Yolande (1990). Femmes de parole. Histoire des Cercles de Fermières du Québec, 1915-1990. Montréal: Le Jour.

Crenshaw, Kimberle (1991). Mapping the Margins: Intersectionality, Identity Politics, and Violence against Women of Color. Stanford Law Review, 43 (6), 1241-1299.

DAvIS, Natalie Zemon (2011). Decentering History: Local Stories and Cultural Crossings in a Global World. History $\mathcal{E}$ Theory, 50 (2), 188-202.

ERIKson, Amy (1993). Women and Property in Early Modern England. London: Routledge.

FARRAGHER, John Mack (1981). History from the Inside-Out: Writing the History of Women in Rural America, American Quarterly, 33 (5), 537-557.

FroIsSART, Tony \& TERRET, Thierry (2014). Peasant vulnerability, rural masculinity and physical education in France, from the early twentieth century to the libération. $R u$ ral History, (25), April, 61-77.

García GonzÁlez, Francisco (2020). Vivir en soledad.Viudedad, soltería y abanono en el mundo rural (España y América Latina, siglos XVI-XXI). Madrid/Frankfurt: Iberoamericana/Vervuert

Goose, Nigel (ed.) (2007). Women's Work in Industrial England: Regional and Local Perspectives. Hatfield: University of Hertfordshire Press.

GraYzeL, Susan (1999). Nostalgia, Gender, and the Countryside: Placing the 'Land Girl' in First World War Britain. Rural History, 10 (2), 155-170.

GRIM, Valerie (2012). The Black Farmers Class Action Lawsuit Against the United States Department of Agriculture, 1997-2010. In Debra ReID \& Evan BenNetT 
(Eds.), Beyond Forty Acres and a Mule: African American Farm Families after Freedom (pp. 271-296). Chapel Hill: University of North Carolina Press.

HaRTMAn, Mary S. (2004). The Household and the Making of History: a subversive view of the Western past. Cambridge: Cambridge University Press.

Humphries, Jane \& WeISDORF, Jacob (2015). The Wages of Women in England, 12601860. Fournal of Economic History, 75 (2), 405-447.

InHetveEn, Heide \& Schmitt, Mathilde (eds.) (2000). Pionierinnen des Landbaus. Uetersen: Heydorns Verlag.

JELlison, Katherine (2009). Entitled to Power: Farm Women and Technology, 1913-1963. Chapel Hill: University of North Carolina Press.

JENKINS, Inez (1953). The History of the Women's Institute Movement in England and Wales. Oxford: University Press C. Batey.

JEnsen, Joan M. (1981). With These Hands:Women Working on the Land. NewYork: Feminist Press.

Jensen, Joan M. (2000). Now You See Her, Now You Don't. Historians and Rural Women". In Kenneth E. Koons \& Warren HofsTRA (Eds.), After the Black Country. Rural life in the GreatValley ofVirginia, 1800-1900 (pp. 221-232). Knoxville: University of Tennessee Press.

Jensen, Joan M. (2006). Calling this Place Home.Women on the Wisconsin Frontier, 18501925). St. Paul: Minnesota Historical Society Press.

Johnson, Colin R. (2013). Fust Queer Folks: Gender and Sexuality in Rural America. Philadelphia: Temple University Press.

Jones, Elizabeth B. (2009). Gender and Rural Modernity: Farm Women and the Politics of Labor in Germany, 1871-1933. Farnham: Ashgate.

JoNES, Lu Ann (2002). Mama Learned Us to Work: Farm Women in the New South. Chapel Hill: University of North Carolina Press.

Jones, Rachel (2016). Gender, Crime Opportunity and Landscape in Nineteenth-Century Wales. Rural History, 27 (2), 169-185.

LERNER, Gerda (1975). Placing Women in History: Definitions and Challenges. Feminist Studies, 3 (1), 4-14.

LitTle, Jo \& PANELli, Ruth (2003). Gender research in rural geography. Gender, Place and Culture, 10 (3), 281-289.

McCallum, Claire E. (2018). The Fate of the New Man: representing and reconstructing masculinity in Soviet visual culture, 1945-1965. De Kalb: Illinois.

McDonagh, Briony (2017). Elite Women and the Agricultural Landscape, 1700-1830, London: Routledge.

Neth, Mary C. (1995). Preserving the Family Farm:Women, Community, and the Foundations of Agribusiness in the Midwest, 1900-1940. Baltimore: John Hopkins University Press. 
O'Hara, Patricia (1998). Paterns in production? Women, farm and family in Ireland. Oxford: Berghahn Books.

ORTEGA LóPEZ, Teresa (Ed.) (2015). Fornaleras, campesinas y agricultoras. La historia agraria desde una perspectiva de género. Zaragoza: PUZ

Ortega López, Teresa María \& Cabana, Ana (2021). "Haberlas, haylas". Campesinas en la historia de España en el siglo XX. Madrid: Marcial Pons.

OsBorne, Harvey D. (2016). Unwomanly practices. Poaching Crime, Gender and the Female Offender in Nineteenth-Century. Rural History, 27 (2), 149-168.

Osterud, Nancy Grey (2012). Putting the Barn Before the House: Women and Family Farming in Early Twentieth-Century New York. Ithaca: Cornell University Press.

Rey CASTELAO, Ofelia (2015). El trabajo de las mujeres rurales en la España Moderna.Un balance historiográfico, 1994/2013. Revista de Historiografía, (22), 183-210.

Rich, Adrienne (1972). When we Dead Awaken: Writing as Re-Vision. College English, 34 (1), 18-30.

RoBerTs, Michael (1979). "Sickles and Scythes: Women's Work and Men's Work at Harvest Time". History Workshop fournal, (7), 3-28.

Rosenberg, Gabriel N. (2015). The 4-H Harvest: Sexuality and the State in Rural America. Philadelphia: University of Pennsylvania Press.

Rowntree, B. Seebohm (1910). Land and Labour: Lessons from Belgium. London: Macmillan.

SACHS, Carolyn (1983). The Invisible Farmers. Woman in agricultural production. Totowa \& New Jersey: Rowman and Allanheld

SAINCLIVIER, Jacqueline (2005). Une histoire des agricultrices aux XIXe-XXe siècle est-elle possible en France? Acquis et perspectives. In Nadine VIVIER (Ed.), Ruralité française et britannique XIIF-XXe siècles. Approches comparées (pp. 117-128). Rennes: Presses Universitaires de Rennes.

SANGERES, Lise (2002). The Cultural Representation of the Farming Landscape: Masculinity, Power \& Nature. Fournal of Rural Studies, 18 (4), 373-84.

SARAsúa, Carmen \& GálVEz, Lina (Ed.) (2003). ¿Privilegios o eficiencia? Mujeres y hombres en los mercados de trabajo. España, siglos XVIII a XX. Alicante: Publicaciones de la Universidad de Alicante.

SARASÚA, Carmen (Ed.) (2021). Salarios que la ciudad paga al campo. Las nodrizas de las inclusas, 1700-1900. Alicante: Publicaciones de la Universidad de Alicante

SAWAHn, Anke (2009). Die Frauenlobby vom Land. Die Landfrauenbervegung in Deutschland und ihre Funktionärinnen 1898-1948. Frankfurt am Main: DLG Verlag.

SAYER, Karen (1995). Women of the Fields: Representations of Rural Women in the Nineteenth Century. Manchester: Manchester University Press. 
SCHILSTRA, Wietsche N. (1940). Vrouwenarbeid in landbouw en industrie in Nederland in de tweede helft der 19de eeuw. Amsterdam: Uitgeverij Contact (reprint Nijmegen, Socialistische Uitgeverij, 1976).

ScotT, Joan W. (1986). Gender: A Useful Category of Historical Analysis. American History Review, 91 (5), 1053-1075.

SEGALEN, Martine (1980). Mari et femme dans la société rurale. Paris: Flammarion.

SHARPE, Pamela (1996). Adapting to Capitalism: working women in the English economy, 1700-1850. Basingstoke: Macmillan.

SHTEIR, Ann B. (1996). Cultivating Women, Cultivating Science: Flora's Daughters and Botany in England, 1760-1870. Baltimore: John Hopkins University Press.

SMIT, Greta G. (1966). Het landbouwhuishoudonderwijs in Nederland. Onstaan, ontwikkeling en betekenis 1908-1965. 's-Gravenhage: Staatsuit-geverij.

SPICKSLEY, Judith M. (2007). "Fly with a Duck in Thy Mouth": Single Women as Sources of Credit in Seventeenth-Century England. Social History, 32 (2), 187-207.

UekötTer, Frank (2010). Die Wahrheit ist auf dem Feld. Eine Wissensgeschichte der deutschen Landwirtschaft. Göttingen:Vandenhoeck-Ruprecht Verlage.

UlBRICH, Claudia (1995). Überlegungen zur Erforschung von Geschlechterrollen in der ländlichen Gesellschaft. Historische Zeitschrift, (18), 359-364.

Verdon, Nicola (2002). Rural Women Workers in Nineteenth-Century England: Gender, Work and Wages. Woodbridge: Boydell \& Brewer.

Whatmore, Sarah (1991). The Farming Women: GenderWork and Family Enterprise. London: Macmillan.

WhITE, Bonnie (2014). The Women's Land Army in First World War Britain, London: Palgrave MacMillan.

WhitTLE, Jane (2019). A critique of approaches to domestic work: women, work and the pre-industrial economy. Past and Present, 243 (1), 35-70. 